\title{
EUROSCEPTIC ATTITUDES TOWARDS THE TRANSATLANTIC TRADE AND INVESTMENT PARTNERSHIP: WHO ARE THE TRENDSETTERS AND FOLLOWERS?
}

Filip TERESZKIEWICZ, PhD

Faculty of Economy and Management, Opole University of Technology, Poland

f.tereszkiewicz@gmail.com

\begin{abstract}
Since the Hooghe et al.(2002) publication about party positions on European integration, a comparison of radical right and radical left Eurosceptic parties is not often conducted. In literature about Euroscepticism, the image of the horseshoe or "inverted U" illustrates the orientation of Euroscepticism among parties without any deeper analysis. This paper tries fill the research gap by investigating whether these two Eurosceptic groups are distinct from each other in the area of EU trade policy by analyzing the debate surrounding the Transatlantic Trade and Investment Partnership (TTIP). Using European Parliament debates about this EU-US partnership, the author tries give answers to the following questions: are Eurosceptic Members of the European Parliament (EMEPS) unified in their attitudes towards the TTIP? Between the far right and far left, which group of EMEPs was the trendsetter in the TTIP debate and which was the follower? To answer these questions, a constructivist approach is applied through discourse analysis. In the conclusion, the author concludes that far-left Eurosceptics are trendsetters on the issue, and those on the far-right are the followers. In the contrast to the far-left parties, being opposed to free trade with the US was not consistent with the ideological profile of the far-right parties. Therefore, the latter had to change their attitudes towards this treaty, following the rise of anti-TTIP attitudes in European society.
\end{abstract}

Keywords: Euroscepticism, EU trade policy, TTIP, Far-left, Far-right, European Parliament

\section{Introduction}

Political parties and movements with distinct anti-European platforms have gained considerable electoral representation in recent years (Adam, 2017; Rooduijn et al., 2017; Halikiopoulou, 2018). Despite this process, there is still scant research on how and to what extent Eurosceptic activity shapes public policy or public discourse (Leruth, Startin and Usherwood, 2018). Szczerbiak and Taggart confirm this problem, remarking that there is little research that analyses the influence of Euroscepticism on EU politics (Szczerbiak and Taggart, 2018). This paper fills the research gap in the area of the Eurosceptic Members' of the European Parliament (EMEP) opinion on EU trade policy by analyzing the debate about TTIP that was negotiated during 
the EP's $6^{\text {th }}$ and $7^{\text {th }}$ terms. For far-left parties and groups, who have historically been opposed to neo-liberalism, opposition to TTIP has understandably played an increasingly important role not only in political campaigns but also in differentiating themselves from mainstream parties. However, if being in the opposition towards TTIP is understandable for far-left Eurosceptics, the debate about the EU-US trade partnership has shown that far-right Eurosceptic politicians were also against this treaty. This observation is interesting because far-right parties mostly support capitalism and free trade, even if it is linked to the EU. The situation begs the question of why farright Eurosceptics reversed their positions on free trade, and where they differ from far-left competitors in their attitudes toward global trade. Since the publication by Hooghe et al.(2002) about party positions on European integration, the comparison of radical right and radical left Eurosceptic parties is not often conducted. In literature about Euroscepticism, the image of the horseshoe or "inverted U" is widely used to illustrate the orientation of Euroscepticism among parties without any deeper analysis. Therefore, this paper contributes to filling gaps in our knowledge about differences between far-right and far-left Eurosceptics and their respective influences. The second goal of this paper is to scrutinize whether EMEPs are coherent or divided in their attitudes towards EU trade policy by using the ongoing debate surrounding the TTIP. To achieve this goal, two questions are asked: Are EMEPs unified in their attitudes towards the TTIP? Which group of EMEPs was the trendsetter in the TTIP debate, and which was the follower: the radical right or the radical left? To answer these questions, a constructivist approach is applied through discourse analysis.

This paper proceeds as follows: the first section provides an analysis of Euroscepticism. The far-right and far-left Euroscepticism typology is chosen for the foundation of this paper, and differences and similarities between the two are described. The second section briefly defines of trendsetters and followers. Third, the paper sheds light on Eurosceptic discourse and behavior within EP activity on TTIP. The fourth and final section reveals which EMEPs are trendsetters and which are followers on the TTIP issue followed by a conclusion.

\section{Defining Euroscepticism}

Even though the first notion of Euroscepticism was conceived in 1998 by Taggart (2003), it is still difficult to say that Euroscepticism, as a concrete idea, exists. Taggart and Szczerbiak's 
definition states that it is a phenomenon "encompassing a range of critical position on European integration, as well as outright opposition" (2004, pp. 5-6). However, this definition has weaknesses that are common with other definitions of the term because they emphasize its negative and fuzzy character. Further, they do not speculate as to why this negative attitude exists, offer any alternatives to integration, or postulate what end it leads to, creating confusion over what exactly links Eurosceptic movements and groups aside from negative attitudes (Leruth, Startin and Usherwood, 2018).

In analyzing Euroscepticism, many approaches have been used to distinguish them: 'hard' and 'soft' Euroscepticism (Taggart and Szczerbiak, 2004); "Euro-rejects", "Eurosceptics" and "Euro-pragmatists" (Kopecký and Mudde, 2002); "Rejectionist Euroscepticism”, "Conditional Euroscepticism" and "Compromising Euroscepticism" (Vasilopoulou, 2011); and Far Right Euroscepticism (FRE) and Far Left Euroscepticism (FLE) (Meijers, 2017). The latter typology is chosen for the foundation of this paper. According to Hooghe et al., Euroscepticism is a far-left and far-right phenomenon because the EU expands in competency from liberalization of markets and opening up of domestic economies to competition toward more direct involvement in the functioning of member states' legal systems and social programmes (Hooghe, Marks and Wilson, 2002). However, radical right and left parties do not only hold anti-European views, but that their Euroscepticism is a crucial point of their ideological profiles. Both types of parties believe that European integration is a particularly salient policy issue. However, they are in opposition to the EU for very different reasons (Meijers, 2017). Most of all, FREs accuse the EU of eroding national culture, and FLEs criticize the EU as a vehicle of domination and exploitation of the working class (Halikiopoulou, Nanou and Vasilopoulou, 2012; Meijers, 2017). While FREs try to combine cultural identity arguments against the EU with utilitarian objections against the pooling of sovereignty, the FLEs' wariness about the EU is a product of their opposition to the free market economy and their quest for economic and social justice (Hooghe, Marks and Wilson, 2002). Moreover, as Halikiopoulou et al. write, the electoral rise of the FLEs has been mostly a trend in the European periphery, being the form of protest against the EU in the context of austerity policy forced by EU institutions (2012). In contrast to that, the development of FREs has been ubiquitous across EU member states, "from Scandinavia to the Mediterranean and from the Benelux countries to the post-communist nations" (Startin and Brack, 2017). 
Using the FRE/FLE typology, three Eurosceptic factions existed during TTIP negotiations in the EP's $7^{\text {th }}$ and $8^{\text {th }}$ terms:

Confederal Group of the European United Left - Nordic Green Left (GUE - NGL: radicalleft group), Europe of Freedom and Democracy/Europe of Freedom and Direct Democracy (EFD/EFDD: radical-right group), and Europe of Nations and Freedom (ENF: radical-right group). However, it should be noted that some independent MEPs are also Eurosceptics.

\section{Definitions of trendsetters and followers}

Although there is no common definitions within political science what trendsetter and follower mean, terms are used by researchers (Lewis, 1999). For example, Ilbiz and Curtis note that trendsetters exert a significant influence, and also shape agendas and norms. Although this definition could be useful for this analysis, their definition of followers, which states that "followers are not as strong or influential as trendsetters" and "have comparatively limited influence on setting trends" is inaccurate; according to them, a follower exerts some influence on others, which in essence means that followers are also trendsetters (Ilbiz and Curtis, 2015).

In this paper, the trendsetter is defined as a politician, party, or faction that creates and promotes trends, such as opinions about a particular decision within EU politics, while a follower is, in contrast, a similar entity that acts according to the actions of the trendsetter. To assess which Eurosceptic politician and group in EP (far-right or far-left) play a trendsetter role among EMEPs on the TTIP issue, this paper poses the following questions: Does it set Eurosceptic discourse about a certain topic? Does it present unique arguments during debates? Do other Eurosceptic MEPs echo them?

To distinguish between trendsetters and followers, two further questions are considered: do they change their attitudes towards TTIP following public debate? Do they start using arguments that have been popular amongst European societies and other politicians?

The investigation of who plays trendsetter and follower roles in parliamentary TTIP debates is achieved by analyzing speeches through Critical Discourse Analysis (CDA). Since the 1980s, discourse analysis has become a highly-favoured method of empirical analysis, especially

among constructivist and critical international relations scholars. However, the terms discourse and discourse analysis do not have a standard definition, so it follows that there is not a single 
method of discourse analysis. Düzgit and Rumelili note that a wide range of scholars use discourseanalytical tools in various ways - some more loosely and illustratively, others more systematically (2018). As such, there are important theoretical differences between scholars employing discourse analysis in terms of whether (and to what extent) individual discursive practices can shape and modify discourse, which shows that notions of discourse are central to the study of interaction practices in institutional settings like the EP. Jaworski and Coupland's research into discourse analysis shows that discourse is "language use relative to social, political and cultural formations - it is language reflecting social order but also language shaping social order, and shaping individuals' interaction with society" $(1999,3)$. Therefore, EP discourse about TTIP can be used to shape an attitude towards this treaty, not only in this EU institution, but also in the EU as a whole.

Additionally, the research is extended on quantitative methods. To show the dynamic of MEP attitudes towards TTIP, voter shifts between pro- and anti-TTIP camps are also presente, demonstrating a change of position in the FRE and FLE camps.

\section{Eurosceptic Members of European Parliament attitudes towards TTIP}

EP resolutions are a political instrument that facilitates the EU's governing body to influence negotiations in international trade. Usually the EP approves these acts before formally beginning negotiation, as well as during the negotiation process. The last step is EP approval for an international trade agreement. Therefore, resolutions and preceding debates are used by MEPs to show areas of their disagreement with a specific motion. Sometimes, when an issue is controversial, MEPs postulate a European Commission (EC) or Council statement to resolve their doubts, and debates are also conducted after these statements.

Three debates about TTIP were conducted within the EP. In May 2013, MEPs discussed the resolution on trade and investment agreement negotiations with the US (EU trade and investment agreement negotiations with the US (debate), 2013); in July 2014 they deliberated in the Commission statement on TTIP (Commission statement: Transatlantic Trade and Investment Partnership (TTIP), 2014); and in July 2015 they debated the resolution on negotiations surrounding TTIP (Negotiations for the Transatlantic Trade and Investment Partnership (TTIP) (debate), 2015). 
Voting on first resolution shows that the overwhelming majority of MEPs supported the resolution (461 for, 105 against, 30 abstentions). Among the pro-TTIP camp were the European People's Party (EPP), Group of the Progressive Alliance of Socialists and Democrats (S\&D), European Conservatives and Reformists Group (C\&R), Group of the Alliance of Liberals and Democrats for Europe (ALDE), part of Europe of Freedom and Democracy Group (EFD). The anti-TTIP camp consisted of the Group of the Greens/European Free Alliance (Greene/EFA), Confederal Group of the European United Left - Nordic Green Left (GUE/NGL), part of EFD, and independent MEPs.

This voting shows that FRE MEPs were divided on the TTIP issue. Among members voting for were those from Danish People's Party (DF - Dansk Folkeparti), Finns Party (PS Perussuomalaiset), Greater Romania Party (PRM - Partidul România Mare), Jobbik, the Movement for a Better Hungary (Jobbik - Jobbik Magyarországért Mozgalom), Northern League (LN - Lega Nord), Party of Order and Justice (PTT - Partija tvarka ir teisingumas), Party of Freedom (PV - Partij voor de Vrijheid), Solid Poland (SP - Solidarna Polska), and UK Independence Party (UKIP). Against the resolution were Freedom Party of Austria (FPÖ Freiheitliche Partei Österreichs), National Front (FN - Front national), the Slovak National Party (SNS - Slovenská národná strana), Flemish Interest (VB - Vlaams Belang), part of Jobbik, and PV. Some members of UKIP abstained.

FLE MEPs, in the contrast to their counterparts, were coherent in voting. Against the resolution were Communist Party of Bohemia and Moravia (KSCM - Komunistická strana Čech a Moravy), Communist Party of Greece (KKE - Kommounistikó Kómma Elládas), Croatian Labourists - Labour Party (HL -SR - Hrvatski laburisti - Stranka rada), French Communist Party (PCF - Parti communiste français), Left Bloc (BdE - Bloco de Esquerda), Left Party (V Vänsterpartiet), People's Movement against the EU (FmEU - Folkebevagelsen mod EU), Progressive Party of Working People (AKEL - Anorthotikó Kómma Ergazómenou Laoú), Sinn Féin (SF), Socialist Party (SPa - Socialistische Partij), Socialist Party of Latvia (LSP - Latvijas Sociālistiskā partija), Syriza, the German Left (die Linke), Unitary Democratic Coalition (CDU Coligação Democrática Unitária), and United Left (IU - Izquierda Unida).

The overall prevailing opinion among all MEPs was that TTIP is necessary and good for the EU. For FRE MEPs the issue wasn't controversial; they occasionally took part in the debate about resolution. In remarks, they underlined that their support for the partnership depends on 
particular regulations, and in large part they didn't attack TTIP. Some of them focused on how small and medium enterprises (SME) could be affected under TTIP rules, others stressed a necessity to preserve protected geographical indications and traditional specialties, doubting the ability of the EC to conduct an effective negotiation (See table no. 1). UKIP's MEPs underlined that Britain has a deep economic relationship with US, therefore the TTIP would make this partnership redundant (EU trade and investment agreement negotiations with the US (debate), 2013).

FLE MEPs during this debate were markedly against TTIP. They emphasized threats that could emerge out of the new EU-US partnership. Concerns that could dominate public opinion in coming years were present in their speeches: anxiety about GMOs, the secrecy of negotiation, anxiety over Investor-state dispute settlement (ISDS), the decline of labor rights protection, the decline of consumer rights, and degradation of food standards, e.g. chlorinated chickens, meat with hormones (see table no. 1) (EU trade and investment agreement negotiations with the US (debate), 2013).

Table 1: Number of arguments used during the debate in 2013

\begin{tabular}{|l|l|l|}
\hline Arguments: & ERL & ERR \\
\hline anxiety about GMOs & 4 & - \\
\hline anxiety of ISDS & 3 & - \\
\hline chlorinated chickens & 1 & - \\
\hline meat with hormones & 1 & - \\
\hline degradation of food standards & 2 & - \\
\hline TTIP's effect on SMEs & - & 2 \\
\hline a necessity to preserve protected geographical indications and traditional specialties & - & 1 \\
\hline the secrecy of negotiation & 4 & - \\
\hline decline of labor rights protection & 2 & - \\
\hline decline of consumer rights & 2 & - \\
\hline
\end{tabular}


The next debate on the Commission statement was conducted in the EP on $15^{\text {th }}$ July 2014. No voting was held after this debate, so analysis of distribution is not possible. However, the discussion shows us the arguments used by both sides. The analysis of the FRE MEP arguments during this debate points out that the salience of the TTIP issue increased. Furthermore, they moved to an anti-TTIP position because arguments that were being used by these MEPs were unfavorable for the partnership (see table no. 2). Moreover, they started using arguments that were heard in FLE speeches in the previous EP debate, such as anxiety about GMOs, meat with hormones, and the secrecy of the TTIP negotiations. However, the necessity to preserve protected geographical indications and traditional specialties was the most popular argument being used by FRE MEPs, especially form France and Italy. Only Petr Mach from Party of Free Citizens (SSO Strana svobodných občanư) supported free trade with the US, though he doubted the ability of the EC to conduct effective negotiations (Commission statement: Transatlantic Trade and Investment Partnership (TTIP), 2014).

The FLE' position was stable. A rejection of the partnership was mentioned as one of their most important goals for the new EP term, citing a decline of labor rights protection as the primary reason for opposition. However, agricultural issues, degradation of the environment, and privatization of public services were visible in their arguments as well. A decline in the salience of the GMO argument is notable here because none of the FLEs mentioned it (see table no. 2), especially because they played up this anxiety often during the previous debate (see table no. 1) (Commission statement: Transatlantic Trade and Investment Partnership (TTIP), 2014).

Table 2: Number of arguments used during the debate in 2014

\begin{tabular}{|l|l|l|}
\hline Arguments: & ERL & ERR \\
\hline anxiety over GMOs & - & 3 \\
\hline anxiety over ISDS & 3 & 2 \\
\hline meat with hormones & - & 3 \\
\hline degradation of food standards & 3 & 1 \\
\hline TTIP's effect on agriculture & 5 & 1 \\
\hline
\end{tabular}




\begin{tabular}{|l|l|l|}
\hline $\begin{array}{l}\text { a necessity to preserve protected geographical indications and traditional } \\
\text { specialties }\end{array}$ & - & 4 \\
\hline the secrecy of negotiations & 3 & 3 \\
\hline decline of labor rights protection & 8 & 1 \\
\hline decline of consumer rights & 2 & - \\
\hline degradation of the environment & 5 & 1 \\
\hline privatization of public services & 5 & \\
\hline personal data protection & 2 & 1 \\
\hline doubt about the ability of the EC to conduct effective negotiations & - & 2 \\
\hline undemocratic character of procedures & 2 & 1 \\
\hline
\end{tabular}

As was mentioned before, the second resolution was adopted on $8^{\text {th }}$ July 2015 , two years after the first. As shown in the EP debate in July 2014, the political situation around TTIP changed dramatically, as anti-TTIP movements became more popular and encouraged societies to oppose this partnership (Eliasson and Huet, 2018). Voting on the resolution in the EP exposed a shift in the opinion about TTIP; though the pro-TTIP camp (consisting of EPP, the majority of S\&D, ALDE, and C\&R) was victorious with 436 votes, the anti-TTIP bloc grew (consisting not only of GUE/NGL and Greene/ALE, but also EFDD, EFN, and independent MEPs), garnering 241 votes against it in the process.

MEP voter shift to the anti-TTIP camp was observed among FREs. Against the resolution were Congress of the New Right (KNP - Kongres Nowej Prawicy), Five Star Movement (M5S Movimento 5 Stelle), FPÖ, Golden Dawn (LS-CA - Laïkós Sýndesmos - Chrysí Avgi), Jobbik, Liberty (Wolność), LN, National Democratic Party of Germany (NPD - Nationaldemokratische Partei Deutschlands), NF, part of UKIP, SSO, and VB. However, members of four parties broke ranks, as some MEPs from UKIP, as well as the entirety of SD and VB abstained. Furthermore, the majority of VP didn't take part in the voting, though they were present in the hall. 
FLE MEPs were still coherent in their attitudes toward TTIP. Against the resolution were AKEL, BdE, die Linke, FmEU, Galician Alternative of the Left (AGE - Alternativa Galega de Esquerda), IU, KKE, KSCM, Left Alliance (VAS - Vasemmistoliitto), Left Front (FG - Front de Gauche), Party for the Animals (PvdD - Partij voor de Dieren), Podemos, Popular Unity (LAE Laikí Enótita), Portuguese Communist Party (PCP - Partido Comunista Português), SF, Syriza, SPa, The Other Europe with Tsipras (AET - L'Altra Europa con Tsipras), and V.

The discussion about the second resolution shows that there was still a majority in the EP that supported TTIP. However, the topic became salient because the number of MEPs taking part in discussions increased. Furthermore, the voting and debate confirmed that the majority of FRE MEPs moved from "pro" or "abstain" positions to "against", although SD, VB, VP and part of UKIP remained neutral. Scrutiny of the debate shows that among the "against" camp of the FRE MEPs are two groups. The first maintains an absolute opposition that consisted of FPÖ, Jobbik, LN, M5S, and NF. These MEPs rejected this treaty stressing hazards such as a decrease in food security, anxiety over ISDS, growth of unemployment rate in the EU, and unfair competition for European SMEs and agricultural firms from US companies. The second group is less resolute in their opposition, emphasizing support for global free trade. TTIP has, according to them, too many regulations. Their main concerns were ISDS, and privatization of public services (LS-CA SSO, UKIP) (Negotiations for the Transatlantic Trade and Investment Partnership (TTIP) (debate), 2015). Interestingly, there is an absence of the necessity to preserve protected geographical indications and traditional specialties argument, which was popular among FREs in later debates (see table no. 2 and no. 3).

The FLE MEPs' argument held firm from previous debates, with the most popular touchpoints being the decline of labor rights protection, anxiety over ISDS, and the privatization of public services (Negotiations for the Transatlantic Trade and Investment Partnership (TTIP) (debate), 2015). The consistency among FLE MEPs was observed in the voting as well as the reasoning, although the view of the voting process as undemocratic became more prevalent. (see table no. 3). 
Table 3: Number of arguments used during the debate in 2015

\begin{tabular}{|l|l|l|}
\hline Arguments: & ERL & ERR \\
\hline anxiety over GMOs & - & 3 \\
\hline anxiety over ISDS & 7 & 11 \\
\hline chlorinated chickens & - & 3 \\
\hline meat with hormones & - & 4 \\
\hline degradation of food standards & 4 & 6 \\
\hline TTIP's effect on SMEs & 2 & 5 \\
\hline TTIP's effect on agriculture & 4 & 3 \\
\hline the secrecy of negotiations & - & 2 \\
\hline decline of labor rights protection & 7 & 2 \\
\hline decline of consumer rights & 1 & 2 \\
\hline degradation of the environment & 1 & 1 \\
\hline privatization of public services & 5 & 4 \\
\hline personal data protection & - & 1 \\
\hline $\begin{array}{l}\text { doubt about the ability of the EC to conduct effective } \\
\text { negotiations }\end{array}$ & - & - \\
\hline undemocratic character of procedures & 6 & 1 \\
\hline
\end{tabular}

\section{Which Eurosceptic MEPs are trendsetters and which are followers?}

FLE MEPs were trendsetters on the TTIP issue, especially among Eurosceptic MEPs. Their influence on European societies in several EU member states was recognized by academics (Fabry, 2015; Bluth, 2016; Eliasson and Huet, 2018). FLE parties and movements profoundly affected opinions of European societies on TTIP, having had the ability to channel anxieties into 
the STOP TTIP, and increased the salience of this topic during the EP elections in 2014 (Keith, 2017). In the EP, GUE/NGL (and also Greene/ALE) were against TTIP from the beginning, and therefore had a consistent narrative regarding the treaty, presented in the $7^{\text {th }}$ and $8^{\text {th }}$ terms of the EP. The TTIP issue was important for FLEs because of their ideological profile. As mentioned above, far-left parties are against the EU mainly because of its neoliberal direction in the European integration process. The new partnership with the US was for them the quintessence of global capitalism and evidence that international corporations are steering the Union in the direction that is against popular interest. This narrative steadily gained traction in European societies, and is evidence that FLE MEPs initially used arguments that have become popular in the public discourse. Furthermore, many of those arguments were taken up by the FRE in the next debates, confirming that FLE MEPs were trendsetters among Eurosceptic MEPs.

As a result, FRE MEPs were followers. In 2013, this topic was not on their agenda, so they debated their position rarely. The lack of interest in this issue came from the ideological profile of FREs. TTIP, as an economic issue, didn't draw their attention because it had no direct influence of national identities and values, and was not linked with immigration. There was no reason for them to take part in debates about the new partnership with the US. Furthermore, because differences in attitudes toward trade liberalization, they were divided in the voting even as a majority of them were pro-TTIP. If FRE MEPs had objections to the partnership, they were focused on the weakening of SMEs and the necessity to preserve protected geographical indications and traditional specialties. However, in 2014 and 2015, they became increasingly radicalized. FRE MEPs started using the same arguments as their FLE counterparts, attributing them to public opinion. They followed the public anxiety about TTIP influence on the European economy, not to mention standards created by FLE MEPs during the 2014 elections and the FLEestablished STOP TTIP (Keith, 2017). Only two arguments were typical for the FREs: during the first and second debates they mentioned the necessity to preserve protected geographical indications and traditional specialties, and they voiced concern about SMEs under TTIP rules, indicating that FREs are concerned more about economic sovereignty, especially compared to FLE.

In trying to understand FLE progress and FRE failure to control the debate surrounding TTIP, the spotlight has to be placed on specific issues that were used debates, such as food-safety 
and ISDS. These issues help raise the salience of TTIP generally, which in turn allows lobbying, protests, and campaigns on technical details and other specifics. At the beginning, GMOs and the American process of chlorinated microbial wash of poultry was a natural choice of focus as it connected an appealing food with chemicals. FLE MEPs presented American standards as 'weak' and 'less safe' in public statements. In large part, the European public has increasingly agreed (Eliasson and Huet, 2018, 104-105). According to Garcia-Duran and Eliasson, these controversial issues were strategically chosen by FLEs in order to maximize the perceived threat to consumer interests and safety posed by TTIP, which helped them convince other MEPs and the European public opinion that TTIP would harm product safety and public health, and therefore helped them to increase the salience of this topic $(2017,26)$. All in all, TTIP has been presented as a trade-off between neo-liberalism (or 'wild-west capitalism') and 'popular sovereignty', which is consistent with FLE sources of EU critique.

\section{Conclusions}

The above-conducted analysis shows that Eurosceptic Members of the European Parliament were divided in their attitudes toward TTIP. Far Left Eurosceptic MEPs were against the partnership from the beginning because they are against neoliberal capitalism and free trade. They were also coherent in their attitudes towards TTIP as an example of global capitalism because of their ideological profile. In contrast, Far Right Eurosceptic MEPs are not coherent in their attitude towards EU trade policy and therefore not coherent in their attitude towards TTIP. These attitudes also had roots in their ideological profile. Because of the division of FREs in their attitude towards economic issues (Lefkofridi and Michel, 2014), two groups can be distinguished: "neoliberals" who support global free trade, and "anti-liberals" who are against globalization, especially in the economic dimension. However, after anti-TTIP attitudes were promoted in European societies by FLEs, most FREs have changed their opinion about this treaty. These observations may be important for EU trade policy. Cooperation between FLEs and some FREs on EU trade policy is possible in the EP and member states. The TTIP issue has shown that this cooperation can change opinion on a European level about some aspects of EU trade policy and therefore change a society's attitude toward it. For that reason, the European Commission should think about bringing FREs into the pro-free trade camp if it wants to increase economic 
cooperation between the EU and the rest of the world. It is possible, as some studies show, that FRE MEPs are not resolutely against EU activity in external trade policy (Tereszkiewicz, 2018).

\section{Acknowledgements}

The article is funded by the National Science Centre in Poland under the project "Eurosceptics towards EU external actions and security policy: a constructivist analysis", no. 2018/02/X/HS5/02313.

\section{References}

1. ADAM, R. (2017) 'A Populist Momentum in the EU?', On-line Journal Modelling the New Europe, (23), pp. 19-30. doi: DOI:10.24193/OJMNE.2017.23.02.

2. BLUTH, C. (2016) Attitudes to global trade and TTIPP in Germany and the United States. Gütersloh: Bertelsmann Stifung. Available at: https://www.bertelsmannstiftung.de/fileadmin/files/BSt/Publikationen/GrauePublikationen/NW_Attitudes_global_ trade_and_TTIP.pdf [Accessed 26.04.2019].

3. Commission statement: Transatlantic Trade and Investment Partnership (TTIP) (2014). Strasbourg: European Parliament. Available at: http://www.europarl.europa.eu/sides/getDoc.do?pubRef=//EP//TEXT+CRE+20140715+ITEM-009+DOC+XML+V0//EN (Accessed: 20.07.2019).

4. DÜZGIT, S. A. and RUMELILI, B. (2018), 'Discourse Analysis: Strengths and Shortcomings', All Azimuth, 0, pp. 1-21.

5. ELIASSON, L. J. and HUET, P. G.-D. (2018) 'TTIP negotiations: interest groups, antiTTIP civil society campaigns and public opinion', Journal of Transatlantic Studies, 16(2), pp. 101-116. doi: 10.1080/14794012.2018.1450069.

6. VAN ELSAS, E. J., HAKHVERDIAN, A. and VAN DER BRUG, W. (2016) 'United against a common foe? The nature and origins of Euroscepticism among left-wing and right-wing citizens', West European Politics, 39(6), pp. 1181-1204. doi:

10.1080/01402382.2016.1175244.

7. $\quad$ EU trade and investment agreement negotiations with the US (debate) (2013).

Strasbourg: European Parliament. Available at:

http://www.europarl.europa.eu/sides/getDoc.do?pubRef=- 
//EP//TEXT+CRE+20130522+ITEM-017+DOC+XML+V0//EN (Accessed: 15.07.2019).

8. FABRY, E. (2015) France: A Hotbed of Opposition to the TTIP? 136. Paris-Berlin: Notre Europe Jacques Delors Institut. Available at: http:/www.institutdelors.eu/wpcontent/uploads/2018/01/francettip-fabry-jdidgap-june15.pdf?pdf=ok [Accessed 30.04.2019].

9. HALIKIOPOUlOU, D. (2018) 'A Right-wing Populist Momentum? A Review of 2017 Elections Across Europe', JCMS: Journal of Common Market Studies, 56(S1), pp. 63-73. doi: $10.1111 /$ jcms. 12769 .

10. HALIKIOPOULOU, D., NANOU, K. and VASILOPOULOU, S. (2012) 'The paradox of nationalism: The common denominator of radical right and radical left euroscepticism', European Journal of Political Research, 51(4), pp. 504-539. doi: 10.1111/j.14756765.2011.02050.x.

11. HOOGHE, L., MARKS, G. and WILSON, C. J. (2002) 'Does Left/Right Structure Party Positions on European Integration?', Comparative Political Studies, 35(8), pp. 965-989. doi: $10.1177 / 001041402236310$.

12. ILBIZ, E. and CURTIS, B. L. (2015) 'Trendsetters, Trend Followers, and Individual Players: Obtaining Global Counterterror Actor Types from Proscribed Terror Lists', Studies in Conflict \& Terrorism, 38(1), pp. 39-61. doi: 10.1080/1057610X.2014.974400.

13. JAWORSKI, A. and COUPLAND, N. (1999) 'Introduction: Perspectives on Discourse Analysis', in Jaworski, A. and Coupland, N. (eds) The Discourse Reader, Abingdon: Routledge, p. 1-37.

14. KEITH, D. (2017) "“Stop TTIP”: towards a transnational Eurosceptic opposing the Transatlantic Trade and Investment Partnership?', in FitzGibbon, J., Leruth, B., and Startin, N. (eds) Euroscepticism as a Transnational and Pan-European Phenomenon. The emergence of a new sphere of opposition. London \& New York: Routledge, pp. 97-112.

15. KOPECKÝ, P. and MUDDE, C. (2002) 'The Two Sides of Euroscepticism: Party Positions on European Integration in East Central Europe', European Union Politics, 3(3), pp. 297-326. doi: 10.1177/1465116502003003002.

16. LEFKOFRIDI, Z. and MICHEL, E. (2014) 'Exclusive Solidarity? Radical Right Parties and the Welfare State', Robert Schuman Centre for Advanced Studies Research Paper, 2014/120. Available at: https://ssrn.com/abstract=2539503 [Accessed 30.07.2019]. 
17. LERUTH, B., STARTIN, N. and USHERWOOD, S. (2018) 'Defining Euroscepticism. From a broad concept to a field of study', in Leruth, B., Startin, N., and Usherwood, S. (eds) The Routledge Handbook of Euroscepticism. Abingdon: Routledge, pp. 1-10.

18. LEWIS, P. (1999) 'Parties and Parliaments in East Central Europe: Poland as a TrendSetter', Ten Years After: Democratic Transition and Consolidation in East Central Europe. Budapest.

19. MEIJERS, M. J. (2017) 'Radical Right and Radical Left Euroscepticism: a Dynamic Phenomenon', Jacques Delors Institut Policy Paper, 191. Available at: https://www.delorsinstitut.de/2015/wpcontent/uploads/2017/04/20170407_Euroscepticism-Meijers.pdf [Accessed 30.07.2019].

20. Negotiations for the Transatlantic Trade and Investment Partnership (TTIP) (debate) (2015). Strasbourg: European Parliament. Available at: http://www.europarl.europa.eu/sides/getDoc.do?pubRef=//EP//TEXT+CRE+20150707+ITEM-004+DOC+XML+V0//EN (Accessed: 21.07.2019).

21. ROODUIJN, M. et al. (2017) 'Radical distinction: Support for radical left and radical right parties in Europe', European Union Politics, 18(4), pp. 536-559. doi: $10.1177 / 1465116517718091$.

22. STARTIN, N. and BRACK, N. (2017) 'To Cooperate or Not to Cooperate? The European Radical Right and Pan European Cooperation', in FitzGibbon, J., Leruth, B., and Startin, N. (eds) Euroscepticism as a Transnational and Pan-European Phenomenon: The Emergence of a New Sphere of Opposition. London: Routledge, pp. 28-45.

23. SZCZERBIAK, A. and TAGGART, P. (2018) 'Contemporary Research on Euroscepticism. The state of the art', in Leruth, B., Startin, N., and Usherwood, S. (eds) The Routledge Handbook of Euroscepticism. Abingdon: Routledge, pp. 11-21.

24. TAGGART, P. (2003) 'A Touchstone of Dissent: Euroscepticism in Contemporary Western European Party Systems', European Journal of Political Research, 33(3), pp. 363-388. doi: 10.1111/1475-6765.00387.

25. TAGGART, P. and SZCZERBIAK, A. (2004) 'Contemporary Euroscepticism in the party systems of the European Union candidate states of Central and Eastern Europe', European Journal of Political Research, 43(1), pp. 1-27. doi: 10.1111/j.14756765.2004.00143.x. 
26. TERESZKIEWICZ, F. (2018) 'Visegrad Euroscepticism: Discursive Nodal Points in Eurosceptic Discourses Surrounding External Actions of the European Union', On-line Journal Modelling the New Europe, 26, pp. 144-168.

27. VASILOPOULOU, S. (2011) 'European Integration and the Radical Right: Three Patterns of Opposition', Government and Opposition, 46(2), pp. 223-244. doi: 10.1111/j.1477-7053.2010.01337.x. 